Maurer School of Law: Indiana University

Digital Repository @ Maurer Law

1994

\title{
Informal Agency Actions and U.S. Administrative Law - Informal Procedure in a Global Era
}

Alfred C. Aman

Indiana University Maurer School of Law, aaman@indiana.edu

Follow this and additional works at: https://www.repository.law.indiana.edu/facpub

Part of the Administrative Law Commons

\section{Recommended Citation}

Aman, Alfred C., "Informal Agency Actions and U.S. Administrative Law -- Informal Procedure in a Global Era" (1994). Articles by Maurer Faculty. 578.

https://www.repository.law.indiana.edu/facpub/578

This Article is brought to you for free and open access by the Faculty Scholarship at Digital Repository @ Maurer Law. It has been accepted for inclusion in Articles by Maurer Faculty by an authorized administrator of Digital Repository @ Maurer Law. For more information, please contact rvaughan@indiana.edu. 
ALFRED C. AMAN, JR.

\section{Informal Agency Actions and U.S. Administrative Law - Informal Procedure in a Global Era}

\section{INTRODUCTION}

Informal agency actions in the United States have been described as "the lifeblood of the administrative process," 1 constituting nothing less than "the everyday business of an administrative agency's agenda." 2 Despite, or perhaps, because of the breadth of these descriptions, there never has been a particularly good definition of informal agency actions. They usually are defined negatively - that is, they are those actions not covered by the formal adjudicatory and rulemaking provisions of the U.S. Administrative Procedure Act (APA). Informal actions in the U.S. thus constitute a residual category of agency actions, encompassing a great variety of governmental actions that take a number of administrative forms.

The General Reporter suggests a definitional conception of informal agency actions based on their legally non-binding effects against citizens and/or administrative agency units. Administrative guidelines, warnings, advice and the like are given as examples of this kind of action, relating to citizens. Working with this broad conceptual definition, the general reporter also suggests three types of such informal administrative action: (1) those "addressed to subordinate administrative organs (officers) and . . . legally binding on them but not directly on citizens . . ; (2) actions addressed to subordinate administrative organs but . . . legally binding neither on them nor on citizens"; and (3) actions which are addressed directly to citizens but are not legally binding on them ..."

This paper shall focus primarily on the third category, those informal actions that affect citizens directly, as well as those that are, at least, initially, legally non-binding. Two areas of informal agency action shall be explored and, in so doing, we shall see that "binding"

AlFred C. Aman JR., is Dean and Professor of Law, Indiana University School of LawBloomington.

1. Final Report of the Attorney General's Committee on Administrative Procedure, S. Doc. No. 8, 77th Cong., 1st Sess. 35 (1941). (1992).

2. Alfred C. Aman Jr. \& William Mayton, Administrative Law Treatise 257 
is a relative term. Part III of this paper shall first consider a variety of informal actions described generally as administrative equity. Waivers, exceptions, declaratory orders and the like are sometimes binding on the party that seeks them, but they are sought voluntarily. The "voluntary" nature of exceptions applications is, however, usually based on the costs of the regulation they seek to have waived; they are not binding until they are "voluntarily" sought, but there are often strong incentives to pursue such relief. Declaratory orders and more informal agency advice, however, usually result in nonbinding, but persuasive agency action. This paper shall then consider conditional orders and so-called voluntary commitments that become binding only because the applicants or potential licensees "voluntarily" agree to these conditions.

To set the basic analytic framework within which to examine informal agency actions in general, as well as the role that conditions and administrative equity play in particular, Part II shall first consider the role that informal agency actions have played historically in the United States. In so doing, we shall examine the nature of the kinds of cases and regulatory programs that lend themselves to informal actions, as well as certain considerations involving the timing of the informal actions taken. We also shall consider the relationship of procedure to the underlying philosophical premises that govern the role that the state plays or is expected to play in administering these regulatory regimes. Closely related to this analysis are three additional factors: the increasingly important questions involving the amount of governmental resources available for carrying out regulatory missions, the economic, promotional aspect of the substantive regulatory programs involved, and the degree of regulatory intrusiveness into market processes represented by various regulatory regimes.

\section{Informal Agency Actions and U.S. Administrative LaW - An Historical Perspective}

The 1940 Report to the Attorney General on Administrative Procedure made very clear not only the importance, but the widespread nature of informal actions in American administrative law: ${ }^{3}$

Every administrative agency is charged with administering or enforcing, in the field which Congress has marked out for it, provisions of law which affect private interests. To do this requires the investigation and decision of great numbers of particular cases. In most of these, resort may be had to formal proceedings with testimony of witnesses, stenographic

3. Attorney General's Final Report on Administrative Procedure, supra n. 1, at 35 (1940). 
record, briefs, arguments, and findings of fact or opinion. But despite the fact that formal procedure is generally available, it is of the utmost importance to understand the large part played by informal procedure in the administrative process. In the great majority of cases an investigation and a preliminary decision suffice to settle the matter. Comparatively few cases flower into controversies in which the parties take conflicting positions of such moment to them that resort is necessary to the procedure of the courtroom.

That report went on to make clear that "the great bulk of administrative decisions are made informally and by mutual consent." 4 In so doing, it discussed various contexts in which such informality was likely, such as, for example, the investigatory stage of tax regulation. Millions of returns are filed each year; hundreds of thousands of audits occur, and hundreds of thousands of adjustments are made. A few of these adjustments lead to formal proceedings, but most decisions to make these adjustments are made informally. The sheer number of applications or returns involved necessitates such cooperation if this kind of regulation is to work. There have, therefore, to be persuasive reasons and effective incentives for taxpayers to operate informally and to accept such informal governmental determinations. The relative clarity of the tax law involved, the costs of more formal dispute processes, the ultimate sanctions involved if taxes are not timely paid and the likelihood of prosecutorial success in cases where audits are done and disagreements persist are important factors militating in favor of informal resolution of tax disputes. Formal proceedings generally are likely to be used in difficult cases where the law is not clear and much is at stake.

The 1940 Attorney General's Report also focused on regulatory regimes and decisions that turn on inspections and tests. As the Report notes, "the soundest procedure in cases of this type is that which recognizes the reality that the inspection or test is and must be the decisive element. . . . Protection, in cases such as these, can be afforded by a right to reexamination or reinspection by another and more experienced inspector, far more than by any right to a formal hearing before an official who must merely listen to testimony."

Another category of cases are those involving "large numbers of claims and license applications." ${ }^{1}$ As the Report notes, "in cases of this type formal proceedings in the first instance are undesirable from the point of the individual and the Government. The number of cases alone makes such formal proceedings impossible without in-
4. Id.
5. Id. at $37-38$.
6. Id. at 38 . 
creasing personnel out of all reason."7 Finally, the 1940 Report points to other regulatory contexts in which informality is regularly the norm: those involving emergency agency actions that must be taken before any formal proceedings are possible, ${ }^{8}$ or consent dispositions prior to issuance of a formal complaint. ${ }^{9}$

All of these types of cases - mass justice cases involving enormous numbers of applicants, investigatory cases involving distinct, individual factual situations, emergency situations necessitating that the government act first and hear later, and consensual dispositions were generated, in large part (but not exclusively), by various New Deal regulatory regimes then taking hold. Since 1940, and especially since 1946, when the Administrative Procedure Act was passed, these kinds of cases and the informality that accompanied their disposition have remained an important part of U.S. administrative law, even with the level of deregulation that occurred in the 1980's. ${ }^{10}$ The Administrative Procedure Act itself recognized certain informal actions in Section 555(e).11 More important, section 706(a) of the APA, in effect, labelled agency action not covered by the APA as "committed to agency discretion." 12 In Citizens to Preserve Overton Park $v$. Volpe ${ }^{13}$ however, the Supreme Court construed this provision narrowly, thereby potentially subjecting a great deal of informal agency action to judicial review. Informal agency actions, however, have long been and remain a very important part of U.S. administrative law. Even if judicial review is possible, the timing, stakes and nature of the transactions involved often render judicial review impractical.

Since passage of the APA, a second wave of regulatory law and new regulatory structures have come into being. This regulatory expansion occurred largely in the late 1960's and especially throughout the 1970's, and it resulted in the establishment of a variety of new environmental, health and safety regulatory regimes and structures. ${ }^{14}$ The new regulation involved was detailed, far reaching and created just as much a need for informal agency action, if not more, as existed under the more economically and single industry oriented

7. Id. at 39 .

8. Id. at 40.

9. Id. at 41 . (1992).

10. See Alfred C. Aman Jr., Administrative Law In A Global Era, Chapter 2

11. Section 555(e) states that "prompt notice shall be given of the denial in whole or in part of a written application, petition, or other request of an interested person made in connection with an agency proceeding. Except in affirming a prior denial or when the denial is self-explanatory, the notice shall be accompanied by a brief statement of the grounds for denial.

12. 5 U.S.C. $\$ 706$ (a). See generally, Shapiro, "APA: Past, Present and Future," 72 Va. L. Rev. 447, 452-54 (1986).

13. 401 U.S. 402 (1971).

14. See generally, Aman, "Administrative Law in the United States, Past, Present and Future," 16 Queens L.J. 179, 188-190 (1991). 
regulatory missions of New Deal agencies. Safety and health regulations created new emergency situations, often requiring quick, effective governmental action. Meanwhile, the expansion of welfare and disability programs in the 1970's also created just as much pressure for efficient adjudication of non-controversial cases, if these programs were to function effectively. Since these new programs did not supplant the pre-existing New Deal structures of the past, the reasons for and the economic programs in which the informal action outlined in the 1940 Report was taken continued. In addition, the new overlay of even more detailed and sweeping regulation often required even more administrative flexibility. Thus, there is little doubt that informal agency actions should remain the "lifeblood of the administrative process;"15 however, for a variety of reasons there has also been, over time, an increasing degree of formalization or judicialization of various administrative processes.

The underlying consensus supporting the New Deal and the 1946 APA has always represented an uneasy compromise between those who favored market solutions to economic problems, and thus, distrusted government, and those who advocated affirmative governmental intervention, and thus, had more faith in the ability of government to achieve collective economic goals. ${ }^{16}$ As the APA has matured, and as the relatively uneasy consensus underlying the role of government as defined by that Act began to break down, increasing formalization, usually in the form of judicialization, but also in the form of more complicated congressional procedural mandates could be observed. Those that distrusted government often sought procedural protection from the government. Even those inclined to trust governmental action began to suspect that government was too easily captured by the regulatory interests it was presumed to regulate. Such philosophical presuppositions vis-a-vis the vulnerability of agencies also often militated in favor of more procedure, more transparency and, ultimately, less informality.

Perhaps the most dramatic change in procedural approaches in the 1970's compared to the New Deal era came in the form of the legislative procedures mandated for rulemaking in the environmental, health and safety contexts. The relatively minimal procedures provided by the informal rulemaking provisions of Section 553 of the APA were substantially increased with hybrid rule-making procedures, incorporating aspects of adjudication into the rulemaking process. ${ }^{17}$ Judicialization of the administrative process also increased,

15. Atty. Gen. Report, supra n. 1, at 35 .

16. See Shapiro, supra n. 12; see also, Wong Yang Sung v. McGrath, 339 U.S. 33 (1950).

17. For a discussion of such statutes and a brief history of three eras of administrative law - the New Deal, the Environmental and the Global eras - see Aman, supra n. 10. 
giving rise to far more complicated regulated structures and rulemaking procedures than previously existed at the outset of the New Deal. If anything, such formalization of the rulemaking process accentuated the need for or, in any event, the use of, more informal agency procedures such as exceptions and waivers (see below), but this increasing formalization was, perhaps, both a forerunner to and a partial cause of the deregulation movement that took hold in the 1980 's. The regulatory paralysis in which some of these procedural demands resulted made it more difficult and more costly for many agencies to regulate, quite apart from the more ideological question of whether such regulation should occur at all. For some, regulation remained unnecessary; but for others, it seemed, unfortunately, ineffective and ultimately not worth its cost.

A part of the deregulation movement in the 1980's was thus grounded in the ideological belief that many governmental actions could and should be completely displaced by the market. Not unlike the laissez-faire era of the early 20 th century, such a view tended to see governmental action as unnecessarily intrusive and violative of individual economic rights. Procedure was necessary as an essential form of protection from the government. Depending upon the degree of market intrusiveness involved, the more the better. On the other hand, a second strand of the deregulatory era of the 1980's tended to see the market more as an effective regulatory tool. Thus, market principles and incentive regulation were viewed not in opposition to government, but as an effective form of collective action. As I have argued elsewhere, the global era in which we now live and the frequency and intensity of global competition affecting most regulated industries has made such market approaches more and more attractive. The costs of domestic regulation now stand out in stark relief when compared to other countries that have little or no regulatory costs and low labor costs as well. ${ }^{18}$ Thus, it is in this context that market regulatory approaches are encouraged. The procedures used, like the substantive regulation involved, are judged in terms of their efficiency and effectiveness. Thus, rather than procedural protection from the government, procedures are to advance a new, more market oriented approach to government.

It is this second philosophical strand of the deregulation movement that is reflected in the recent report issued by Vice President Gore's task force on re-inventing government. ${ }^{19}$ This report advocates a wide variety of reforms aimed at streamlining and downsizing government, thereby making it more efficient and effective. The market

18. Id.

19. Vice President Al Gore, Report of the National Performance Review, "From Red Tape to Results: Creating a Government That Works Better and Costs Less," Sept. 7, 1993. 
and market forces are to be harnessed for the public good. Government intervention is viewed positively, but its costs must be minimized. Informality goes hand in hand with a more efficient approach to government. Informal actions can more easily accomplish certain governmental objectives in a more cost-effective way than approaches accompanied by formal procedural approaches. The 1990's, at least the 1990's of the Clinton Administration, thus promise to be a regulatory era in which procedure is not used to thwart government, but rather to facilitate and further what may be more modest regulatory goals, goals that try to rely on market forces and less costly and more informal procedures, where possible.

Quite apart from the philosophical basis of conceptualizing the market as a regulatory tool is the fact that budgetary constraints on government in general and agencies in particular are very real. Given the cuts in federal agency budgets that have and will continue to take place, doing the same or, if possible, doing more with less resources and in new, less intrusive ways is very much the motto of federal administrative agencies today. Budgetary reality, too, will create pressures to proceed informally and efficiently, whenever possible. For example, it is likely that as agency budgets are cut, the number of agency lawyers available to enforce agency rules will be smaller. Of necessity, they will have to seek more informal methods of enforcement, perhaps having to accept negotiated settlements that appear far less ambitious when compared to the agency's public interest goals and the regulatory solutions it may have sought in the past. At the same time, to the extent that substantive, command-control regulatory rules and regimes are replaced with more market oriented, incentive based regulatory schemes, such as those in environmental law that rely more on emissions trading rather than specific rules, enforcement itself is likely to change. Rather than focusing on individual violations of specific regulations, the focus of the future is more likely to be on broad regulatory targets and goals. Such an approach may require less in enforcement resources; it is likely to yield more negotiation, and less formal litigation. ${ }^{20}$

In sum, we have entered a new age of administrative law and reform. It is likely to be one in which informal agency actions remain at least as important as before and, because of the desire to advance the various market oriented goals of both the regulated and the agen-

20. Along with the trends toward market based, incentive regulation, there also are now in place two relatively new statutes that encourage agency settlement and the use of various alternative dispute resolution techniques at the agency level and a negotiated approach to rulemaking. The Negotiated Rulemaking Act, in particular, seeks to encourage negotiating approaches to rulemaking and the production of rules more appropriate for and more acceptable by the industries to which they apply. See Administrative Dispute Resolution Act, 5 U.S.C.A. \& 591, et seq. and Negotiated Rulemaking Act, 5 U.S.C.A. $\$ 581$, et seq. 
cies involved, such informal action is likely to increase, particularly if it increases governmental efficiency. It is with this background and this prediction for the future in mind that we shall now examine two common and related forms of informal agency actions prevalent in a variety of administrative programs.

\section{Administrative Equity and Conditional Orders}

As noted above, informal agency actions in the U.S. constitute a residual category. It is impossible to categorize all of the informal actions and the various contexts within which they occur, but some types of informal actions occur in many, if not most, federal administrative agencies. The 1940 Attorney General's Report was able to set forth certain types of cases and contexts where informal processes are best used. We can, however, refine these broad categories further and focus on two specific areas of informal actions which are important now and are likely to remain significant in the future. These include what we shall call Administrative Equity - the use of waivers, exceptions, modifications and the like, and so-called "voluntary commitments" or conditional orders.

Focusing on the use of conditional orders and "voluntary commitments" will enable us to explore the relatively subtle bargaining relationships that are established in governmental programs that, of necessity, create relationships between potential licensees or applicants for a regulatory benefit and the grantor of that benefit, the government. This, in turn, will enable us to explore just how voluntary some of these commitments are in, for example, the context of federal banking law, where most of this data is drawn from. More generally, though, this discussion will have applicability to all administrative processes that require individual applications or licenses to carry on certain activities.

Focusing on administrative equity, waivers and exceptions, in particular, will enable us to explore a form of informal action that is binding on applicants, but voluntarily initiated by them. Such orders are voluntarily sought to release the applicants involved from the rules that otherwise would apply. ${ }^{21}$ We begin with these forms of informal agency actions, first.

\section{A. Administrative Equity}

Administrative equity serves as a bridge between general, collectively determined rules and the reality of the particular case. It refers to a body of substantive principles and norms that, on occasion, may

21. The following sections of this paper in Part III are drawn almost exclusively from my previous work dealing with administrative equity, and conditions, published in Alfred Aman and William Mayton, Administrative Law Treatise (1992), Chapter 9. Parts IIIA and B are reprinted here with permission by West Publishing Company. 
justify the granting of individual exceptions, exemptions or waivers to rules that generally apply to others. Administrative equity is most often concerned with the impact of a regulatory scheme on those who must bear the brunt of its costs. It is usually always the regulated, not the beneficiaries of the regulation, who seek exceptions or modifications to agency rules. The principles used by regulators to grant or deny these requests constitute the substance of administrative equity. They allow the administrator "to rectify the shortcoming. . . of the lawgiver due to the generality of his statement."22

Exceptions, waivers, modifications, and the like can be grouped into three broad categories: hardship exceptions, which are based on the specific factual characteristics of the applicant; policy exceptions that represent regulatory experiments on the part of the agency; and fairness exceptions that have to do with whom or which part of an industry bears the relative burdens of the regulatory costs involved. The more policy oriented the exceptions become and the less tied they are to the individual factual circumstances of the applicants involved, the more the agency risks making major decisions under the guise of individual, informal actions. Such decisions would not necessarily be known to the public at large and clearly would be a misuse of the basic purposes of informal administrative equitable relief: to minimize regulatory costs by enabling applicants to achieve regulatory goals in a cost effective way.

Administrative equity takes many forms. For example, the Department of Energy Act confers on the Secretary specific power to make adjustments to rules of general applicability. ${ }^{23}$ Adjustments include exceptions, exemptions, modifications, rescissions, and interpretations. Similarly, other agencies provide opportunities for modifications ${ }^{24}$ and waivers, ${ }^{25}$ no-action letters, ${ }^{26}$ variances ${ }^{27}$ or rulings. ${ }^{28}$ All of these various adjustments provide a mechanism for relief from general rules for individual applicants. They fall into two broad categories: those that resemble declaratory orders and those that resemble injunctions.

Some adjustments are closely akin to declaratory orders or advisory opinions. ${ }^{29}$ Rulings or interpretations, for example, usually in-

22. Id. at 281, citing Aristotle, Nicomachean Ethics, Book 5, at 142 (M. Ostwald trans. 1962).

23. 42 U.S.C. $\$ 7174$ (a) (Supp. III 1979).

24. See, e.g., 47 U.S.C. $\$ \S 203(\mathrm{~b})(2), 316$ (a)(1976) (modification).

25. 47 C.F.R. \& 1.3 (1989) (waiver procedure) (FCC).

26. See, e.g., Fed. Sec. L. Rep. (CCH) II 76,001.

27. See, e.g., 29 U.S.C. $\$ 665$ (1976).

28. FED. Taxes (P-11) I 26,708 .

29. The APA specifically authorizes the issuance of declaratory orders in the context or formal adjudicatory cases in 5 U.S.C. \$ 554(e). See generally, Powell, "Sinners, Supplicants and Samaritans: Agency Advice Giving in relation to Section 554(e) of the Administrative Procedure Act," 63 N.C. L. Rev. 339, 366 (1985) [hereinafter cited as "Agency Advice Giving"]. 
volve requests to determine whether a particular regulation actually applies to certain facts and, if so, with what result. Such determinations, made before any agency action has been taken, apply only to the petitioner. They generally predate any actual dispute between the agency and a party, are rendered by agency staff and not subject to judicial review. ${ }^{30}$ Similarly, rescissions and modifications usually apply only to particular orders and particular petitioners. Exceptions to rules, as well as waivers, variances, and the like are more like injunctions. The petitioner does not seek a clarification of the application of a rule; he seeks an order indicating that the rule does not, in fact, apply to him at all. This kind of adjustment enjoins the application of the rule to the petitioner. ${ }^{31}$

These kinds of agency actions usually are authorized by statute. Some statutes authorize the agency to grant only exceptions to rules. ${ }^{32}$ Others authorize a wide variety of modifications. ${ }^{33}$ Apart from statutory authorization, an agency's own rules or policy statements often provide authority for similar exceptions. ${ }^{34}$

These statutes or agency rules usually set forth criteria for granting or denying relief. Some statutes contain broad criteria, giving the administrator enormous discretion in applying the standards. For example, the Department. of Energy Organization Act authorizes the Secretary to grant adjustments if there is "special hardship, inequity or unfair distribution of burdens[.]"35 Other acts are more specific in their criteria. The Occupational Safety and Health Act, for example, provides that the Secretary of Labor may grant adjustments to allow "reasonable variances, tolerances, and exemptions ...

30. See Kixmiller v. SEC, 492 F.2d 641, 643-44 (D.C. Ci. 1974) ("we think members of the Commission's staff ... have no authority to make orders". ...). For an analysis of the advice-giving role of administrative agencies, see Powell, "Agency Advice Giving," supra n. 29.

31. There are, in fact, three broad categories of exceptions: hardship exceptions, fairness exceptions and policy exceptions. See Aman, "Administrative Equity," 1982 Duke L. Rev. at 293-323.

32. See, e.g., Natural Gas Policy Act of 1978, 15 U.S.C. § 3412(c) (1988). See generally, Noland \& Penniman, "The FERC Adjustments Process Under Section 502(c) of the Natural Gas Policy Act of 1978," 1 Energy L.J. 79 (1980).

33. See, e.g., National Traffic and Motor Vehicle Safety Act of 1966, as amended, 15 U.S.C. $\$ \S 1410,1417(1988)$; Federal Mine Safety and Health act of 1977,30 U.S.C. $\S \S 811(\mathrm{c}), 811(\mathrm{e}), 814(\mathrm{~g})(1988) ;$ Water Pollution Control Act Amendments of 1972, 33 U.S.C. \& 1342 (1988); Safe Drinking Water Act, 42 U.S.C. $§ 300 \mathrm{~g}-4$ (1982); Nuclear Non-Proliferation Act of 1978, 42 U.S.C. $\$ 2155 a$ (1982); Clean Air Act, 42 U.S.C. $\S 7410$ (1982); Shipping Act of 1916, 46 U.S.C. $\$ \S 814,833 a$ (1982); Communications Act of 1934, 47 U.S.C. $\$ \S 203(b)(2), 214$ (a) (1982) (common carriers), 47 U.S.C. $\$ \S 316$, 359 (1982) (radio); Federal Aviation Act of 1958, 49 U.S.C. app. $\$ \$ 1386(b)(1), 1432(c)$ (1976).

34. See, e.g., F.P.C. Order No. 467, discussed in Pacific Gas \& Elec. Co. v. FPC, 506 F.2d 33 (D.C.Cir. 1974).

35. 42 U.S.C. \& 7194(a) (1982). 
as he may find necessary and proper to avoid serious impairment of the national defense."36

Quite apart from an agency's own enabling act or rules, some courts have suggested that the authority to grant exceptions to rules may be implied as well. ${ }^{37}$ Courts have failed, however, to explain explicitly the basis of this authority and whether it is statutory or constitutional.

Agencies provide for equitable adjustments and rulings with varying degrees of informality. At one end of the spectrum, an agency may interpret its rules and orders over the telephone. A private party may simply speak with agency staff and receive an interpretation of agency law. Questions arise, however, when parties rely on this advice to their detriment. Can the agency change an interpretation once it has given this advice? What if the advice relied upon was wrong? Can a party seek judicial review of such interpretation? Usually an agency is not bound by the advice of its staff ${ }^{38}$ and such advice is not judicially reviewable. ${ }^{39}$ The application of estoppel principles to agency advice depends to a large degree on the extent of the reliance by and the potential harm to the public. ${ }^{40}$ Many agencies, however, agree to be bound by the informal advice, ${ }^{41}$ and, as a practical matter, informal staff rulings are illustrative of what the agency itself is likely to do.

The APA provides that an agency "may issue a declaratory order to terminate a controversy or remove uncertainty" and that such orders are to have binding effect on the agency and the party in-

36. 29 U.S.C. $\S 665$ (1988).

37. See, e.g., Chemical Manufacturers Association v. National Resources Defense Council, 470 U.S. 116 (1985)(upholding the EPA's creation of fundamentally different factor (FDF) variances with respect to toxic pollutants in the face of statutory language prohibiting the modification of standards for toxic pollutants); WAIT Radio $\mathrm{v}$. FCC, 418 F.2d 1153, 1157 (D.C. Cir. 1969) later app 459 F.2d 1203 cert. denied 409 U.S. 1027 (1972). (ordering the FCC to entertain requests for waivers from its "clear channel" rules, noting that "a system where regulations are maintained inflexibility without any procedure for waiver poses legal difficulties"). See also, Heckler v. Campbell, 461 U.S. 458 (1983)(upholding Social Security Administration regulations establishing a "grid" of categories for considering disability appeals, but noting that an administrative law-judge will not apply the rules contained is the guidelines when they fail to describe a claimant's particular limitations. Id. at 462, n.5 and 467 n.11.

But see, Airline Pilots Assoc. Int'l v. Quesada, 276 F.2d 892, 896 (2nd Cir. 1960) (upholding FAA's refusal to grant any exceptions to its rule that all pilots reaching the age of 60 must retire); see also, Starr v. FAA, 589 F.2d 307 (7th Cir. 1978); Rombough v. FAA, 594 F.2d 893 (2nd Cir. 1979) Gray v. FAA, 594 F.2d 793 (10th Cir. 1979) See generally, Comment, "Mandatory Retirement of Airline Pilots: An Analysis of the FAA's Age 60 Retirement Rule," 33 Hastings L.J. 241 (1981).

38. See Wilmington Chem. Corp. v. Celebrezze, 229 F.Supp. 168 (N.D.Ill. 1964).

39. See authorities cited in supra $n .14$.

40. See, e.g., Federal Crop Ins. Corp. v. Merrill, 332 U.S. 380 (1947); but see, Moser v. U.S., 341 U.S. 41 (1951). Discussed in Gellhorn \& Boyer, at 129.

41. See, e.g., 16 C.F.R. $\$ \S 1.1,1.3$ (1990) (Federal Trade Commission); 26 C.F.R. $\$ \S 602.201(\mathrm{a}), 601.201(\mathrm{~d})$ (1990) (Internal Revenue Service). 
volved. ${ }^{42}$ Such declaratory orders qualify as final agency action and are reviewable in federal court. Because such declaratory orders are produced only in the context of formal adjudicatory hearings, they are rare. ${ }^{43}$

The usual situation is somewhat analogous to that of a federal litigant who seeks to challenge a law that has not, as yet, been applied to him. Article III requires that there be a real "case or controversy." 44 Because most agency declaratory advice is informal, such litigants usually lack the requisite standing, and the case is not ripe for judicial review. A litigant that disagrees with an agency's advice or interpretation can most clearly obtain review by ignoring the advice and defending its own interpretation of the law in an enforcement proceeding. In other contexts, the courts may be willing to step in without requiring the party to risk civil or criminal penalties: for example, courts have concluded that in some cases that certain noaction letters issued by the SEC were sufficiently final to justify judicial review. ${ }^{45}$

Since petitioners formally request the agency to waive the application of an otherwise applicable rule, exceptions or waivers usually result in more elaborate procedures, but normally less than formal procedures. Usually the petitioner files an application, and interested competitors often intervene. The denial or grant of relief is usually treated as a final order. Exceptions requests usually focus on the particular needs of the applicants and the peculiar, distinct, and adverse manner in which it is claimed a rule affects those needs. Such exceptions requests are necessarily adjudicatory in nature. Informal adjudicatory procedures are appropriate for such matters, but agency processes vary in this regard. ${ }^{46}$ Some statutes authorizing equitable relief may sometimes trigger the APA's formal adjudicatory procedure. ${ }^{47}$ This, however, is not very common.

42. 5 U.S.C. $\S 554(\mathrm{e})(1988)$

43. For a detailed treatment of this section of the APA, see Powell, "Agency Advice Giving," supra n. 29.

44. See, e.g., Younger v. Harris, 401 U.S. 37, 91 S. Ct. 746 (1971); Samuels v. Mackell, 401 U.S. 66, 91 S. Ct. 764 (1971); Perez v. Ledesma, 401 U.S. 82, 91 S. Ct. 674 (1971). For agency declaratory orders, see Helco Prods. Co. v. McNutt, 137 F.2d 681 (D.C. Cir. 1943).

45. See Medical Committee for Human Right v. SEC, 432 F.2d 659 (D.C. Cir. 1970) vacated, 404 U.S. 403 (1972); but see, Kixmiller v. SEC, 492 F.2d 641 (D.C. Cir. 1974).

46. For a detailed examination of the Department of Energy Exceptions Process, see Schuck, "When the Exception Becomes the Rule: Regulatory Equity and the Formulation of Energy Policy Through An Exceptions Process," 1984 Duke L. Rev. 163.

47. 572 F.2d 872 (1st Cir. 1978), cert. denied 439 U.S. 824 (1978). See, e.g., Seacoast Anti-Pollution League v. Costle. 


\section{B. Conditions and Commitments}

Requests for exceptions, waivers and other adjustments are initiated by the regulated. Such requests may result in clarification of existing law or, in the case of exceptions and waivers, exemption from certain rules altogether. They usually turn on the peculiar circumstances of the Petitioner involved. Agencies also can take the peculiar facts of an applicant into account by tailoring their regulatory powers to that entity.Indeed, somewhat akin to exceptions are conditional orders or an applicant's advance voluntary consent to certain agency actions. While exceptions and waivers often result in less regulation for the regulated entities who seek them, conditions and commitments usually represent a form of more specific, individual regulatory requirements. In both instances, regulation is being shaped largely by the individual needs of the particular regulated entity with which the agency deals.

Agencies usually exercise power to condition their orders on certain actions in response to an application for a license, merger authorization, or some other kind of regulatory permission. In this sense, the agency has something the applicant wants and a regulatory bargaining context potentially may be established. ${ }^{48}$ The procedural and substantive issues in these various application contexts vary, but individualized petitions that seek permission to engage in certain activity, such as building and operating a nuclear power plant or merging with or acquiring a bank as part of a bank holding company enable the agency involved to condition its grant of authority. It can, in effect, say "yes, but" and then provide certain regulatory requirements, often quite specific to the factual circumstances of the applicant involved. Conditional orders can thus be important regulatory tools in certain kinds of programs.

Conditions are particularly common in application proceedings, such as those carried out pursuant to the Bank Holding Company Act. ${ }^{49}$ Because the nature of the application process is informal, a great deal of negotiation occurs between the staff of the Federal Reserve Board (Board) and the applicants seeking Bank Holding Company status or the acquisition of a bank or nonbank. Orders are not so much decreed as they are negotiated and, in that process, condi-

48. For a treatment of agency conditions, see Aman, "Bargaining For Justice: An Examination of the Use and Limits of Conditions by the Federal Reserve Board," 74 Iowa L. Rev. 837 (1989); [hereinafter, "Bargaining For Justice"]. See also, Mashaw and Tomlinson, "The Enforcement Of Federal Standards In Grant-In-Aid Programs: Suggestions For Beneficiary Involvement," 58 Va. L. Rev. 600 (1972). Most application processes are initially informal, though an ultimate denial of the benefits sought in some programs may later result in more formal adjudication. See, e.g., Matthews v. Eldridge, 424 U.S. 319 (1976).

49. 12 U.S.C. § 1842 (1988). See Aman, "Bargaining For Justice" id. 
tions are often attached by the Board before an applicant's request is granted. ${ }^{50}$

Most Board proceedings, particularly at the early stages of the application process, more accurately fit within a negotiation or bargaining model of regulation. A decision made during the early stages of the process appears to be, and often is, a joint decision. The applicant, of course, wishes to have its application granted. The staff may wish to do so, but may be troubled by certain aspects of the proposal. They may suggest changes or condition approval upon commitments the applicant is willing to make. Each party can obtain only what in the end the other is prepared to allow. If staff and petitioner have a different view of the legal significance of the facts presented in a particular application, informal discussions and bargaining may enable one side to move closer to the other's point of view. Regulatory conditions and voluntary commitments often play a significant role in this phase of the process. Particularly from the applicants' point of view, conditions and voluntary commitments are the very currency of the negotiating process. The applicant will agree to conditions he knows will guarantee the successful and speedy grant of his application. The agency will seek conditions that assure it that the applicant merits its standards and advances its policies.

The various substantive contexts in which an agency issues a conditional order or agrees to grant certain authority in light of an applicant's voluntary commitment to carry out or abstain from carrying out certain activities raise a number of issues. In general, these include questions of law, policy and fact. Working at this level of generality, at least five types of agency conditions or commitments are possible. ${ }^{51} \mathrm{~A}$ perfect condition is one the is based on clear law, clear agency policy and is narrowly tailored to the facts of a particular applicant before the agency. This kind of condition allows the agency to tailor its regulatory demands to fit the precise situation of the applicant before it. Such a condition, being so narrow and fact-specific, is unlikely to have any precedential value. It allows the applicant to obtain approval of its proposed action in a manner that ensures the agency's regulatory duties and goals are full carried out. The informal give and take between agency staff and private counsel constitute the only procedure available in most cases involving this kind of informal agency action.

A second kind of condition can be called a policy condition such a condition is fact-specific and within the agency's legal authority, but

50. For the most part, conditions are authorized by the Bank Holding Company Act. See, e.g., Pauline B. Heller, Federal Bank Holding Company Law (1990) § 7.08, I7-62 n.10.

51. For examples of these five types of conditions and an analysis of their substantive and procedural significance, see Aman, "Bargaining for Justice," supra n. 48, at 891-892. 
it may implicate policies not yet fully articulated by the agency. Such conditions can raise procedural issues similar those involved in determining whether an agency should use adjudication or rulemaking when formulating policy. But policy making at so early a stage in the agency's proceedings, however, raises its own difficulties. The bargaining process usually consists of a discussion between a staff member of the agency and private counsel. By voluntarily agreeing to a condition, the applicant knows that it can expedite its petition, but such a conditions or voluntary commitment often are treated as essentially a fait accompli by the agency that reviews the order. Policy made in this manner, especially significant policy, does not begin to receive the kind of public scrutiny applied to the results of rulemaking proceedings. When the case proceeds to consideration by the full commission or board, there may not have been a full policy review. Given the voluntary nature of the commitment it is not likely that courts will review this aspect of the order. Thus, the policy involved receives even less outside scrutiny than if it had been developed in an adjudication. This kind of ad hoc approach to policy making is thus relatively invisible and not necessarily consistent or well thought out. Conditions with significant policy implications are thus not appropriate for the very informal processes of negotiation that occur in such contexts.

An even more controversial third kind of condition is one in which the parties agree to take or forego certain actions over which the agency's actual regulatory authority is uncertain. An applicant eager to close a deal or avoid protracted litigation may be willing to agree to such a condition, thus allowing the agency to extend its regulatory jurisdiction informally and in a manner also is effectively immune from judicial review. A fourth type of agency condition is one that does not relate to the specific facts in the petition of the applicant. Such a condition is wholly prospective in nature and designed to prevent future action that may or may not be contemplated by the applicant. This kind of regulation may avoid future litigation, but it can be particularly coercive when demanded of an applicant whose own factual situation does not necessarily raise or justify the restriction. Finally, a fifth type of condition or commitment is the null condition, one that is clearly beyond the authority of the Commission to impose, and thus not grounded in any known or articulated policy, and is not even fact-specific to the applicant involved.

These types of conditions have both legal and policy effects. Since most of them are negotiated informally, they create law in an entirely informal manner. They usually come out of the bargaining phase of the administrative process and, as such, are not subject to the kinds of procedural checks found in more adversarial phases of the process. Given the often voluntary nature of the agreement between appli- 
cants and agency staff, neither the policy implications nor the respective merits of these conditions are likely to be reviewed either by the full commission granting the applications or a court reviewing the process.

Nevertheless, attaching conditions to orders is an effective regulatory device. Conditions not only allow an application to proceed, but do so in a manner that is legally sound. Overuse of conditions, however, particularly those that are not fact-specific and grounded on reasonably clear agency authority and policy, can raise some thorny questions. Applicants seeking governmental benefits are seldom in a strong bargaining position. Applicants in the Bank Holding Act context, for example, are usually putting together financial deals that require quick action and approval. Their ability to bargain with the agency or pursue litigation to prove their point is likely to be limited by the realities of the transactions they wish to undertake. In such contexts, the voluntary nature of the commitments they enter into may be exaggerated.

Unwise use of conditions can also have adverse policy effects. If the condition agreed to raises important policy issues, it is not likely the full Board will consider it thoroughly. Conditions that have already been agreed upon are likely to be seen as a fait accompli. This is particularly true when the policies involved are not readily apparent, controversial or both. Indeed, the manner in which such conditions are publicized may also have adverse rule of law effects. For example, to the extent that conditions appear only in letters of transmittal between the parties and the agency, they may constitute a form of secret law. This is particularly true if they contain policy implications of significance beyond the particular applicant in the case, and not publicized or made easily accessible.

\section{Conclusion}

Informality and informal actions are and have always been an important part of the U.S. administrative process. This paper has discussed two forms of informal action - administrative equity and conditional orders. It has suggested that the future of informal actions such as these needs to be assessed in a context marked by increasing global competition and the need for increased governmental efficiency. It is likely that administrative equity in market oriented regimes will be seen as actually advancing the market goals of the programs involved rather than as departure from them. To the extent that conditional orders are attached by agencies to assure compliance with market goals, they will be easier to understand as truly voluntary commitments. Indeed, informal action can usefully be analyzed in terms of the extent of support that exists for the governmental action involved, as well as the resources an agency has to carry 
out its statutory mission. As we move toward regulatory regimes that are more market oriented in their substantive goals and the regulatory means by which they achieve those goals, informal agency action is likely to increase. The use of procedure as a source of protection from government is likely to abate, considerably. The use of informal actions to promote economic goals largely shared by industry and government is likely to increase.

At the same time, a second trend in U.S. administrative law is also likely to encourage informality - the lack of budgetary resources most federal agencies now are experiencing. When there are fewer and fewer personnel to administer and enforce traditional agency rules and policies, informal ways of proceeding are likely to result as a matter of necessity. In short, as budgets become tighter and substantive regulation becomes more market oriented, informal action is less likely to be seen as an illegitimate attempt to accomplish certain governmental tasks. Rather, it is increasingly likely to be seen as a cost effective way of enabling government to operate in a more effective, if less ambitious, manner. 
